\title{
International Journal of Business and Management
}

\section{Basic Theoretical Problems in Pension Accounting}

\author{
Junxun Li \\ School of Management, Xi'an Polytechnic University, Xi'an 710048, China \\ Tel: 86-29-8233-0197Ｅ-mail: dmezy@163.com
}

\begin{abstract}
Xiaoyan Wei
Shaanxi Branch, Zhongrui Yuehua Certified Public Accountants Co., Ltd, Xi'an 710068, China

Tel: 86-29-8100-5139_E-mail: yan5252020@sina.com
\end{abstract}

\begin{abstract}
Pension accounting is an important branch of financial accounting and also an active field in studies on accounting theories and practice of accounting. In this paper, authors discuss the property of pension and relevant accounting principles, the content of pension accounting, the pension plan, etc. Authors mainly discuss related problems in enterprise pension planning from types of pension and pension plan.
\end{abstract}

Keywords: Pension, Pension accounting, Pension plan

\section{The origin and evolvement of pension}

Pension, namely retirement pay, refers to a sum of money for retired man. Property of pension is a historical concept and has various explanations during different times. To probe into the property of pension, we must start from the origin and evolvement of pension.

In England, before 20th century, the pension was a kind of largess given by the King to aged respectful officers, or the master to old and hopping servants, or the owner to hired hands. As a reward to their diligent work, the largess can guarantee a comfortable life once they are incapable of work due to poor health.

In China, before last century, almost no document mentions the pension clearly. In those historical documents, the "pension" was separated into "provide for the old" and "money". The explanation for "provide for the old" in Ci Hai (a great Chinese dictionary): an old manner, to give certain qualified aged people wine and food on schedule. The Five Systems in Book of Sites: "to provide for the old, in Yu Dynasty is to follow the Yan manner, in Xia Dynasty with food, in Yin Dynasty with eating manner, and in Zhou Dynasty is to modify those methods and apply all of them. The aged in fifties are supported by counties, in sixties by national primary and middle schools, and in seventies by colleges." Xuan Zheng notes: "national primary and middle schools, in left of the Palace; colleges, in suburb. Yingda Kong explains: "the Huang says: 'four kinds of old people are supported by the Emperor: the first is the respectful and experienced old people; the second is the old people whose sons or grandsons are died for the country; the third is the retired meritorious people; the fourth is common old people at different ages." Therefore, since ancient China, the emperors provide for a few of qualified old people. Besides, from some Chinese folk plays, we can know that in history the emperor usually gives a sum of money to retired officers for life. The money is the "pension".

Apparently, before 20th century, pension appeared in China and foreign countries in a sense. However, the pension in old days is different from that today. Originally, the pension is merely a kind of largess for few people, which has nothing to do with the income during the employment. The pension is to inspire people's motive. In nature, the original pension is a kind of reward. For the emperor, master, or owner, pension is an extra burden. Therefore, if we make accounting treatment with the pension paid by them, the pension should be listed as "non-operating expense" as it happens. Entering $20^{\text {th }}$ century, along with continuous social development and scientific and technological progress, the population rises dramatically and labor supply exceeds the demand. Enterprises, on one hand, have to keep in replacing the low-efficient aged employees for the sake of productivity. On the other hand, medical science prolongs people's life. As a result, lots of aged people without jobs have to maintain their lives for a long time. At the very beginning, the state or the government can provide an allowance for them. Meanwhile, they can make it by themselves or family support. However, retired people are more and more. For example, in 1960 in Japan people above more than 65 years old account for $5.7 \%$ of total population, and in 1988 the percentage reaches $11.2 \%$. In England, the retired people are about $20 \%$ of employed people in 1948 , and in 1978 the percentage rises to $28 \%$. Under this circumstance, the state allowance and family support are far from sufficiency. Therefore, the duty to help the retired people maintain their lives must fall 
to enterprises which they have worked for. In fact, the improved overall efficiency derived from replacing the old can ensure the expenses for the retired people. In 1935, the first "Social Security Act" in the world was issued in England. It forces enterprises to improve the pension for employees by law. Afterwards, the pension is not only connected with few people or a largess any more. It has something to do with every employee. The pension's function as a reward disappears accordingly.

Obviously, in modern times, pension is the costs paid by enterprises for replacing aged employees because of their low inefficiency in order to maintain high overall productivity. Therefore, for retired employees, to obtain pension is a legal right. For enterprises, to pay for pension is a duty. The sum of pension is based on labors of employees. It is a part of employees' total salaries. In nature, it is a kind of deferred payment for labors, namely the "deferred wage". From an accounting angle, according to the accrual basis, as a kind of deferred payments for labors, the pension should be paid periodically and listed as current costs.

\section{The contents of pension accounting}

Before we study the contents of pension accounting, firstly we look at the popular ways in world for pension calculation and payment. In general, there are three modes: (1) Enterprises deduct and save pensions according to certain proportion and manage the pensions by themselves. As employees are retired, enterprises will pay off pensions in one time or several times. (2) Enterprises deduct pensions according to certain proportion and give them to a special institution manipulated by the state to manage the pensions. As employees are retired, the special institution will pay off pensions in one time or several times. (3) Enterprises buy pension insurances for employees. As employees are retired, the insurance company will pay off pensions in one time or several times. Based on the three modes, the contents of pension accounting include two parts. Firstly, the enterprises accountants deal with the pensions as deferred labor payments periodically and ensure enterprises' duties. Secondly, the pension accounting is under the control of enterprises or special institutions or insurance companies. To be exact, the second part belongs to the scope of fund accounting. It concerns pensions' investments in funds, return, increase, and decrease, and should be calculated by many professionals.

\section{The pension plan}

The sum of pension and its payment directly affect people's daily life, as well as the national finance and taxation. Therefore, it is necessary to organize and manage pensions systematically, and program the pensions. In other words, we must set up a pension plan. In western developed countries, there are two kinds of pension plans in general: the state pension plan and the enterprise pension plan.

\subsection{The state pension plan}

The state pension plan is programmed by the government in general. Its capital resources include appropriations from finance department and fares paid by enterprises and employees according to certain proportion. The state pension plan adopts a two-layer system. At the first layer, the pension is not connected with employees' income. It offers a basic and lowest pension. At the second layer, namely the "accumulated state pension" is associated with the income. Generally speaking, enterprises can replace the "accumulated state pension" with self-constituted enterprise pension plan. In addition, in different countries, their state pension plans account for various percentages of total pensions. In America, England, and France, the proportions of state pension plans to total pensions are low, but the enterprise pension plans develop very well, which accounts for a higher proportion of total pensions. In Italy, conditions are different. At present, population aging brings about high pensions and medical expenses. High welfare policies make the state finance bear more and more burdens. Under this circumstance, enterprise pension plan will become more popular. So do pensions supplied by enterprise pension plans. The proportion of pensions supplied by enterprise pension plans to total pension will keep in rising. Therefore, enterprises will be more careful in constituting pension plans.

\subsection{The enterprise pension plan}

The enterprise pension plan includes the promise of paying pensions according to fixed rules and the finance safety that ensures the payment of pensions. Its capital funds are from fares paid by employees and enterprises. To build up enterprise pension plans means to make a long-term promise for participants, namely employees in enterprises. In order to carry out the promise, enterprises must constitute complete pension plan institutions.

\subsubsection{The procedures of making up enterprise pension plans}

In general, it has three procedures as follow:

(1) Make up written enterprise pension plan, in which specifically regulate the qualifications for employees participating in this plan, the bases for calculating pensions, and how to collect and manage the capitals or assets for pensions.

(2) During the employment period, record expenses for pensions and debts or assets of pensions, and pay appointed pension-entrusted institutions (usually, the pension fund is managed by an entrusted institution that is independent from 
the enterprise) cashes.

(3) As employees are retired, make sure that retired employees can get promised retirement pension from the pension fund. What's more, the pension plan should include other welfares besides pensions, such as medical insurance, after the retirement.

\subsubsection{The types of enterprise pension plans}

The enterprise pension plans have many types. In general, they are:

(1) According to whether employees participate in pay expenses for pensions or not, there are relative participation plan and non-relative participation plan. The first type is to pay expenses for pensions by both enterprises and employees, and the second is by enterprises only.

(2) According to whether employees' pensions are predetermined or not, there are predetermined pension plan and predetermined deposit plan. The first type refers to the pension obtained by employees after retirement. It can be calculated by fixed formula written in pension plan. In other words, it is predetermined. However, enterprises' deposit pension fund is uncertain. It means pension plan's performance risk falls to enterprises. The second is quite the reverse. Enterprises save deposits for pensions in pension fund entrusted institution periodically according to rules in enterprises pension plans. In other words, enterprises deposit pension funds are predetermined. But pensions obtained by employees after retirement are not, which are determined by the operations of pension plans.

Besides, in western countries, an enterprise can make up two or more pension plans, or build up one pension plan with several enterprises, or construct insurance pension plan that is to sign a pension contract with insurance company in name of each employee or the staff. The enterprise pays insurances annually. As employees are retired, they get retirement pay directly from the insurance company. By this way, the enterprise transfers its legal responsibility of paying employees pensions to the insurance company, as well as relevant risks and returns in paying insurances. In general, among all these pension plans, the most typical is the one with employees' relative participation and determined by one enterprise.

\section{Conclusion}

China has already entered the population aging times and to emphasize on the construction of pension system has become an important problem in economic development. After years of practices, western countries have constituted their proper pension insurance systems respectively, as well as a set of perfect system for pension accounting. In China, it is still at an exploration stage. China's pension insurance system reform has begun in 1984 in some pilot districts. After more than ten years' exploration, a set of pension insurance mode right for China comes into being at present. Along with the deepening reform of pension insurance system in China, the construction of China's pension insurance system will improve employees' pensions wholly.

\section{References}

Ministry of Finance, People's Public of China. (2006). Pension Plan (Abridged) --- ARB43. Beijing: China Renmin University Press. p69-70.

Yuan, Zhi. (2005). Practice of Accounting in Private Non-Government Organizations. Beijing: Economic Science Press. p126-127.

Wang, Donghao. (2005). The reform and development of social security system in China. Journal of Sun Yatsen University (Social Science Edition). No.1. p76-77. 